\title{
Oxygen Hyperbaric Exposure Induces GLUT4 Expression Reduction and No Folliculogenesis Alterations in Rat PCOS with Insulin Resistance Model
}

\author{
Varianidia Veterini', Budi Santoso', Widjiati ${ }^{2}$ \\ 'Department of Obstetrics and Gynecology, Dr. Soetomo Hospital, Faculty of Medicine, Airlangga University Surabaya \\ ${ }^{2}$ Department of Veterinary Anatomy, Faculty of Veterinary Medicine, Airlangga University, Surabaya
}

\begin{abstract}
ABSTRAK
Tujuan: Mengetahui pengaruh paparan oksigen hiperbarik terhadap ekspresi GLUT4 dan folikulogenesis tikus mdel SOPK dengan resistensi insulin.

Bahan dan Metode: Penelitian analitik eksperimental menggunakan 30 ekor tikus yang diinjeksi tesosteron propionat $1 \mathrm{mg} / 100 \mathrm{~g}$ BB perhari selama 28 hari sebagai model SOPK dengan resistensi insulin. Hewan coba dibagi menjadi 3 kelompok. Kelompok kontrol negatif tidak mendapat perlakuan apapun, kontrol positif mendapatkan plasebo, dan perlakuan mendapat paparan oksigen hiperbarik 2.4ATA 90 menit 2x5 hari. Ekspresi GLUT4 diperiksa dengan metode imunohistokimia pada $\mathrm{m}$. Gastrocnemius. Pengecatan Hematoxylin Eosin dikerjakan pada ovarium tikus untuk melihat adanya perbedaan folikulogenesis pada ketiga kelompok. Hasilnya kami bandingkan antara 3 kelompok.

Hasil: Didapatkan penurunan bermakna ekspresi GLUT4 pada kelompok perlakuan (rerata $0,84 \pm 0,47$ ) dibandingkan kontrol negatif dan positif (rerata 3,96 $+3,16$ dan 3,36 $\pm 2,17$ ).Tidak didapatkan perbedaan folikulogenesis pada ketiga kelompok $(\mathrm{p}>0,05)$.

Simpulan: Paparan oksigen hiperbarik 2.4 ATA 90 menit selama $2 \times 5$ sesi menyebabkan penurunan ekspresi GLUT4 dan tidak menyebabkan perubahan folikulogenesis pada tikus model SOPK dengan resistensi insulin, sehingga belum dapat digunakan sebagai alternatif terapi pada SOPK.
\end{abstract}

\begin{abstract}
Objectives: To know effect of hyperbaric oxygen therapy to GLUT4 expression and folliculogenesis in rat PCOS with insulin resistent model.

Materials and Methods: this is an analytic experimental study used 30 rats induced by testosterone propionate injection 1 $\mathrm{mg} / 100 \mathrm{~g}$ body weight daily for 28 consecutive days as a PCOS with insulin resistent model. Animal models divided into 3 groups. Negative control was not given treatment, positive control was given placebo. Treatment group was given hyperbaric oxygen 2.4 ATA 90 minutes $2 \times 5$ days. GLUT4 expression determined by immunohystochemistry to $\mathrm{m}$. Gastrocnemius. Hematoxylin Eosin staining to rat ovaries were performed to know differentiation in folliculogenesis. The results were then compared.

Results: There were significant decrease of GLUT4 expression in treatment group (mean0,84+0,47)compared to negative and positive control (mean3,96+3,16and3,36+2,17). There were no different folliculogenesis in these groups.

Conclusion: Hyperbaric oxygen 2.4 ATA 90 minutes $2 \times 5$ days induce decrease of GLUT4 expression and no alterations in folliculogenesis in rat PCOS with insulin resistent model, therefore can not yet be used as alternative therapy in PCOS.
\end{abstract}

Keywords: hyperbaric oxygen, PCOS, insulin resistent, GLUT4, folliculogenesis.

Kata kunci: oksigen hiperbarik, SOPK, resistensi insulin,

GLUT4, folikulogenesis

Correspondence: Varianidia Veterini, Departement of Obstetric \& Gynecology RSUD dr. Soetomo-Medical Faculty of Airlangga University Surabaya, J1 Prof. Dr. Moestopo 6 - 8, Surabaya. Email : varianidiaveterini@gmailcom.

\section{INTRODUCTION}

Polycystic ovary syndrome (PCOS) is the most common cause of ovulatory disturbance in reproductive age women. ${ }^{1}$ According to ESHRE/ARSM, prevalence of PCOS is as high as $15-20 \%$. The experts found long term consequences in PCOS, which is type II DM, hypertension, and cardiovascular disease.PCOS women who become pregnant will have a higher risk of preeclampsia. Endometrial hyperplasia dan endometrial carcinoma often foundin women with PCOS who never get any treatment. Therefore PCOS become a complex medical problem, not only in endocrine reproductive only. $^{2}$

Therapy for ovulatory disturbance in PCOS including anti estrogen agent (clomiphen citrate), aromatase inhibitor (letrozole), ovarial drilling, or gonadotropin injection. Insulin sensitizer (metformin) is also used in PCOS. $80 \%$ women treated with clomiphen citrate will have ovulation, but only $35 \%$ of them will achieve pregnancy. ${ }^{3}$ The aim of this study is to investigate whether hyperbaric oxygen can be used as an alternative therapy in clomiphen citrate-resistant PCOS.

Hyperbaric oxygen (HBO) exposure to DM type II resulted improvement in blood glucose level and insulin sensitivity. ${ }^{4,5,6}$ Although HBO exposure in DM type II have been commonly investigated, there is no study conducted in PCOS. As well as DM type II, insulin resistance is also found in PCOS. Various mechanisms suspected in pathophysiology of insulin resistance, one of them is alteration of tyrosin phosphorylation into serine phosphorylation. Serine phosphorylation known increasing in DM type II, this mechanism is similar with 
insulin resistance in PCOS. Whether HBO exposure has effect to insulin resistant in PCOS is not yet known.

GLUT4 is the main glucose transport molecule and the main regulator of glucose homeostasis in the body. GLUT4 mainly expressed in adipose and skeletal muscle. ${ }^{7}$ Biomolecular basis of HBO treatment is tissue hyperoxia. Increasing oxygen level will induce oxygen metabolism resulting free radicals, ROS and RNS. In mammals, ROS and RNS known as a signalling molecule in many kinase pathway, one of them is PI-3K pathway. ${ }^{8}$ Binding insulin to its receptor will activate this kinase resulting IRS1/2, IRS1/2 then catalyze phosphorylation PIP2 to PIP3. PIP3 induce PKB/Akt expression. Akt is a protein produced by activastion of protein kinase $\mathrm{B}, \mathrm{Akt}$ is the main effector in metabolism regulated insulin. some activity regulated by phosphorylation mediated Akt, one of them is Akt substrat 160 $\mathrm{kDa}$ (AS160). AS160 is the key of intermediate signal, AS160 will induce translocation of GLUT4 to cell membrane, therefore increasing GLUT4 expression. ${ }^{9}$ No is one of the RNS that play roles in increasing AMPK activation. ${ }^{8}$ Increase of AMPK activity will followed by various intracelluler changes that increase GLUT4 expression. ${ }^{10}$ Increasing of GLUT4 expression as glucose transport molecule will increase glucosal uptake, therefore lowering blood glucose level and insulin level.

Decreasing of insulin level will obliterate suppression effect of insulin to SHBG production in liver and increase IGFBP-1 secretion, and also decrease androgen production by theca cell. Decrease of androgen level will ameliorate $\mathrm{FSH} / \mathrm{LH}$ ratio, which in turn will restore folliculogenesis to normal state. Optimum level of FSH will survive antral folicle to become dominant follicle and then become ovulate and produce corpus luteum. ${ }^{11}$ This study is conducted to compare GLUT4 expression and folliculogenesis in rat PCOS with insulin resistant model with and without hyperbaric oxygen exposure.

\section{MATERIALS AND METHODS}

Design of this study is randomized post test only control group,conducted from May-June 2015 in patologyanatomy laboratory Veterinary Medicine of Airlangga University and Hyperbaric laboratory LAKESLA Naval Hospital dr. Ramelan Surabaya. 30 healthy-female, adult, aged 3-4 months Rattus norvegicus (100-120 g) have never been used in another study is included in this study. All of animal were obtained from Pusat Veterinaria Farma (PUSVETMA) Surabaya. Ratshad an adaptation for $2 \times 24$ hours before included in this study. All animal had similar cage and feed with similar food and water ad libitum. Before injected by testosteron propionat (TP) (Testohormon, PT. Wonderindo Pratama) $1 \mathrm{mg} / 100 \mathrm{~g}$ body weight for 28 days sub cutaneously to make PCOS with insulin resistant model, all rats were performed vaginal swab. Only those who had estrus phase would be injected.PCOS model were proven by second vaginal swab after 28 days of injection. Rats that became PCOS model divided into 3 groups : negativecontrol $(\mathrm{n}=10)$ didn't get any exposure, positivecontrol $(\mathrm{n}=10)$ were pulled into animal chamberwith normal air, and treatment groups $(n=10)$ were pulled into animal chamberand had exposure to $100 \%$ oxygen 2.4 ATA 90 minutes for $2 \times 5$ days.

After oxygen exposure was finished, all rats were terminated with $50 \mathrm{mg} / \mathrm{kg}$ body weight ketamine hydrochoride acid (Ketalar). Immunohystochemistry with antibody antiGLUT4 (Polyclonal, Bioss) were performed to Gastrocnemiusmuscle to examine GLUT4 expression. Hematoxylin Eosin staining were performed to ovaries to examine folliculogenesis. GLUT4 expression showed by blue dot in the cell membrane using modified immunoreactive score by Remmelle. ${ }^{12}$ Data on each sample is the mean of IRS observed in 5 randomly visual fields by $40 \mathrm{x}$ magnification using light microscope Nikon H600L withdigital camera DS Fi2 300 MP and software Nikon Image System.

Folliculogenesis that observed in this study consist of secondary follicle (characterized by oocyte surrounded several layer of granulose cell, and already have theca cell, and pellucida zone), tertiary follicle (characterized by several layer granulose cell, interna and externa theca cell, and already have antrum), Graafian follicle (characterized by large antrum, degeneration of granulose cumulus oophorus), and corpus luteum (characterized by luteinized granulose cell, with large nucleus and eosinophilic cytoplasm). Callibrated light microscope Nikon Eclipse $\mathrm{Ci}$ with Digital camera Optilab Plus 12 Megapixel were used to count follicle in 5 random visual field using 40x magnification. ${ }^{13}$ SPSS 20 used in statistical analysis. Kruskal Wallistest followed by Mann Whitney test used to compare of GLUT4 expression. $\mathrm{p}<0,05$ considered significant. Alteration in folliculogenesis defined by differentiation in follicle counting in each stage. Kruskal Wallis performed in abnormal data and Oneway anova performed in normal data.

\section{RESULTS AND DISCUSSION}

Body weight range between 100-120 gram, the mean body weight was $107,00 \pm 8,23 ; 108,50 \pm 8,83$; and $109,00 \pm 7,38$ in negative control groups, positive control groups, and treatment groups. In 3 groups, there were no significant difference in body weight ( $\mathrm{p}: 0,81)$. 
Vaginal swabs in all rats after treatment showed diestrus phase. This showed us that in all rats become persistent estrus, one of PCOS characteristics even after the treatment. GLUT4 expression seen in the Figure 1.
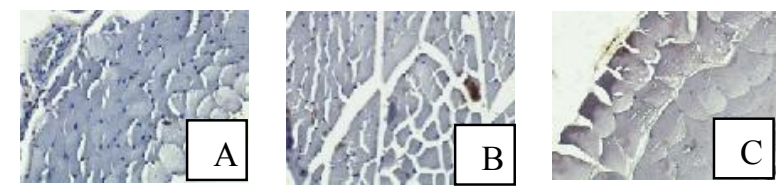

Figure 1. GLUT4 expression characterized by blue dot in cell membrane. (A) negative control, (B) positive control, (C) treatment group

GLUT4 expression in negative control group was in range $0,2-11,0$; the mean was $3,96 \pm 3,16$. Positive control group was in the range $0,2-6,0$ the mean was $3,36 \pm 2,17$; and treatment group was in range $0,4-1,8$ the mean was $0,84 \pm 0,48$. Statistical analysis showed a significant difference between 3 groups ( $\mathrm{p}: 0,01)$. Mann Whitney test used to evaluate difference in each groups. Table 1 showed difference in each groups. There was no difference between negative and positive control groups $(p>0,05)$. There was significant difference between control groups and treatment group $(\mathrm{p}<0,05)$. Surprisingly, GLUT4 expression in the treatment group significantly lower than controls.

Table 1. Comparison of GLUT4 expression between groups

\begin{tabular}{lcc}
\hline & Mann Whitney test \\
\hline Control $(-) /$ Control $( \pm)$ & $\mathrm{P}: 0,67$ & $\mathrm{P}>0,05$ \\
Control $(-) /$ Treatment & $\mathrm{P}: 0,007$ & $\mathrm{P}<0,05$ \\
Control $( \pm) /$ Treatment & $\mathrm{P}: 0,02$ & \\
\hline
\end{tabular}

PCOS model in this study proven by Hematoxylin Eosin staining. Picture 2 showed cystic follicles, and domination of small follicles. Vaginal swab previously performed support this presentation.
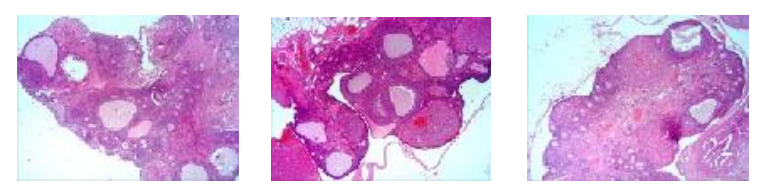

Figure 2. Ovarian HE staining showed charcateristics of PCOS, which is cystic follicles and domination of small follicles.

Mean of follicular count in each stage showed in table 2. Statistical analysis showed no difference between 3 groups. There were Graafian follicle and corpus luteum in all groups, but the number is far below normal. For every ovulation, normal rats can produce 6-10 oosit. These results showed oligo/anovulation in all groups, corresponding to PCOS.

Table 2. Mean of follicular count in each stage.

\begin{tabular}{lllll}
\hline & \multicolumn{4}{c}{ Mean } \\
\cline { 2 - 5 } & SF & TF & GF & CL \\
\hline Control (-) & $34,20 \pm$ & $3,60 \pm$ & $1,40 \pm$ & $1,60 \pm$ \\
& 13,27 & 1,43 & 1,43 & 2,01 \\
\hline Control $( \pm)$ & 24,80 & $3,80 \pm$ & $2,70 \pm$ & $1,30 \pm$ \\
& $\pm 4,94$ & 2,62 & 2,11 & 1,42 \\
\hline Treatment & $31,20 \pm$ & $2,40 \pm$ & $3,50 \pm$ & $1,80 \pm$ \\
& 12,23 & 2,27 & 2,32 & 1,55 \\
\hline Significance & $\mathrm{P}: 0,16$ & $\mathrm{P}: 0,21$ & $\mathrm{P}:$ & $\mathrm{P}: 0,80$ \\
& & & 0,09 & \\
\hline
\end{tabular}

SF: secondary follicle, TF: tertiary follicle, GF: Graafian follicle, CL:corpus luteum

PCOS affects 4-6\% reproductive age female, is the most common cause of anovulation. Based on Rotterdam criteria 2003, PCOS is defined by 2 from 3 criteria found, which are oligo/anovulation, hyperandrogenism, and/or polycystic ovary by ultrasound. Underlying cause of PCOS is still unclear. Role of insulin resistance is suspected in the pathophysiology of PCOS. In the similar blood glucose level, there are higher insulin level in PCOS compared to normal, not related to obesity. This difference shows insulin resistance in PCOS. ${ }^{14,15}$ The etiology of insulin resistance in PCOS is not clearly known. There are various mechanisms that lead to insulin resistance, such as low expression of GLUT4, increase of serine phosphorylation in insulin receptor that will lead to decrease of signal transduction and also depletion of adenosine in celluler. ${ }^{16}$ Unclear etiology complicate therapy of PCOS. Restoration of hyperandrogen is expected by lowering insulin resistance, therefore will improve ovulation.

Various study conducted in human and animal model to know pathophysology and therapy to PCOS. Ideally, study was conducted in human, but it is very difficult.Various animal model had been developed to get characteristic of PCOS as seen in human, but there are no ideal animal model. This study used female Rattus norvegicus injected by TP $1 \mathrm{mg} / 100 \mathrm{~g}$ body weight 28 days consecutively to induce PCOS with insulin resistance model. Model induction based on the previous study. ${ }^{17,18,19}$

\section{Effect of hyperbaric oxygen to GLUT4 expression in PCOS}

Molecular mechanisms underlying insulin activity to glucosal uptake were known from previous in vitro and in vivo study. Insulin increase GLUT4 expression in 
cell membrane of skeletal muscle and adipose. Previous study stated increase of GLUT4 in rat muscle cell from $9,13 \pm 1,03$ in basal state to $20,37 \pm 3,12$ after insulin exposure. ${ }^{20}$ GLUT4 is lower in DM type II than normal $\left(116 \pm 7\right.$ OD unit and $71 \pm 11$ OD unit). ${ }^{21}$ Another study showed similar results. ${ }^{22}$ In PCOS, there are significant lower GLUT4 in muscle cell, unrelated to obesity. ${ }^{23}$ In our literature study, there are no similar study compare GLUT4 expression. Most of them compare blood glucose level, and insulin sensitivity. In this study, we assumed blood glucose level describe GLUT4 in cell membrane. High blood glucose level resulted from disturbance in glucosal uptake. Failure to transport glucose from extracel to intracel caused by reduce GLUT4 expression in cell membrane, therefore low blood glucose level assumed with high expression of GLUT4 in cell membrane.

An increase in serine phosphorylation in insulin receptor was known from previous study using cultured of PCOS muscle cell compared to control.This result activation of PI3K pathway is not work, therefore no translocation of GLUT4 into cell membrane, and disturb glucosal uptake. ${ }^{15}$ In the treatment groups, mean GLUT4 expression is far below the controls. Comparison between negative and positive control showed no difference (p:0,68). Hyperbaric oxygen exposure didn't increase expression of GLUT4, even decrease it.

Decrease of GLUT4 expression was contrary to our hypothesis.We suspected there were another role of extrinsic factor that results in insulin resistance beside inactivation of PI3K pathway due to change from tirosin to serine phosphorylation in PCOS. Those factor are adipokine, mediator of inflammation, and free fatty acid. PCOS known to have increase in all of them. ${ }^{21,22,23,24}$

Hyperbaric oxygen exposure increase oxygen level in the celluler, especially mitochondria. Free radicals formed, act as a signalling molecule in various kinase pathway. Those free radicals could be double edged sword. Many studies reported positive effect of hyperbaric oxygen, but another studies reported negative effect. These negative effects known as "oxygen paradox". Tirosin phosphorylation in adipocyte culture increase due to $\mathrm{H} 2 \mathrm{O} 2$ exposure, those similar effect seen in the insulin exposure. ${ }^{25}$ These contradictive result also found in other study to cultured muscle cell which had exposure to free radicals $\mathrm{H} 2 \mathrm{O} 2$, these resulted in the decrease of GLUT4 expression. ${ }^{26}$ Another study showed decrease of fasting blood glucose level and fasting insulin level in type II DM rats model due to hyperbaric oxygen $1 .^{25}$ ATA 6 hours daily for 4 weeks. $^{27}$
ROS is known can activate various signalling pathway such as FoxO, MAPK, JAK/STAT, p53, Phospolipase $\mathrm{C}, \mathrm{PI}-3 \mathrm{~K}$ and other proteins. But, which signalling pathway would be activated is depends on level of ROS, spesific type of ROS, type of cell, exposure duration, and other factors. ${ }^{28}$ ROS can induce oxidative damage to protein, lipid, nucleic acid, and other cell components through NF- $\kappa \beta .{ }^{29}$

This study used hyperbaric oxygen 2.4 ATA 90 minutes $2 \times 5$ days. This protocol is in the range dose recommended by UHMS based on the evidences, $2.0-$ 2.5 ATA up to 120 minutes until proven no improvement to the underlying disease. ${ }^{30}$ We used this dose based on previous study on type II DM in human and also in rats model. ${ }^{6,31,32}$ These positive effect is contradictive to our study result. We suspected there were different pathophysiology underlie insulin resist-ance in DM type II and PCOS, therefore improvement mechanism in DM type II can't applied in PCOS. We can't conclude yet what the differences are. This study were not measure level of free radicals, and anti oxidant level formed, therefore we can't conclude yet whether this hyperbaric exposure act as oxidative stress. Another study is needed to explain this molecular effect of hyperbaric oxygen.

\section{Effects of hyperbaric oxygen to folliculogenesis}

Unlike human, normal rats can produce several dominant follicle lead to ovulation. Within one ovulation, normal rat release 6-10 oocytes. ${ }^{33}$ Follicle development is depend on gonadotropin in the cyclic recruitment, in this phase some amount of secondary follicle will be tertiary follicle. Inadequate FSH stimulation cause secondary follicle fail to become tertiary follicle, and become Graafian follicle. In this stage, some of follicles will become resting follicle due to inadequate FSH stimulation. $^{33}$

In this study, we found no differences between 3 groups in mean follicle count in each stage. This phenomena could be resulted from decrease of GLUT4 expression, therefore there were no improvement in insulin resistance. Hyperinsulinemia stimulate androgen production, therefore no different folliculogenesis seen in the treatment group compared to controls. We didn't measure insulin level in this study, but we assumed there were no decrease of insulin resistance. Hyperinsulinemia cause hyperandrogen by increasing androgen synthesis by theca interna. ${ }^{15}$ Increasing of insulin level cause granulose cell give earlier response to LH. This could lead granulose cell to produce estrogen which in turn give negative feedback to FSH secretion, therefore there were no optimal FSH to follicle development. 
Induction PCOS model using $\mathrm{TP}$, characteristics of PCOS will be seen 7 days after injection. Ovary will be dominated by preantral follicle, and also found cystic follicles and thicker stroma. After 14 days injection, preantral follicle will increase dan antral follicle will decrease compare to normal. After 28 days injection, no corpus luteum formed along with granulose degeneration in antral follicle, therefore cystic follicle formed. Atretic follicles in antral stage will increase by $80 \%$ compared to normal. Insulin level will also higher compared to controls. ${ }^{19}$ Following androgen exposure, hyperthecosis will be formed. Severity of insulin resistance related to severity of hyperthecosis. Hyperinsulinemia is an important marker of hyperthecosis. ${ }^{11}$

In this study, injection androgen for 28 consequtive days aimed to get a PCOS with insulin resistance model. Due to this prolonged exposure PCOS model could be formed with also hyperthecosis that can't be improved by oxygen exposure. We found mean of corpus luteum were $1,60 \pm 2,01 ; 1,30 \pm 1,42 ;$ and $1,80 \pm 1,55$ in negative control, positive control, and treatment group. These showed us oligoovulation in all groups. Statistical analysis showed no difference $(p>0,05)$. This could be resulted from decrease of GLUT4 expression after hyperbaric oxygen exposure. Hyperandrogen due to hyperinsulinemia leads to decreasing of $\mathrm{FSH} / \mathrm{LH}$ ratio, therefore no dominant follicles were formed. Mean of dominant follicle in negative control, positive control, and treatment groups were $1,40 \pm 1,43 ; 2,70 \pm 2,11$; and $3,50 \pm 2,32$. One of the requirement to ovulation is $\mathrm{LH}$ surge which is stimulated by high estrogen level for some period of time. In PCOS, there were no LH surge. LH surge is needed to increase secreation of Oocyte Maturating Inhibitor (OMI) in granulose cell. This lead to increase of prostaglandin, ad increase progesterone level produced by granulose cell. These will lead to rupture of follicular wall, therefore oocyte will be released, and follicle become corpus luteum.

Similar result were showed by another study by Atis et al., 2012. There were no significant difference in count of primary, secondary, tertiary, and corpus luteum in the rat modelwhich had hyperbaric oxygen exposure and which had not hyperbaric oxygen exposure. In that study, atretic follicles even higherin the group which had hyperbaric oxygen exposure. Cell membrane and DNA damage due to oxidative stress is suspected in this study. ${ }^{34}$

\section{CONCLUSION}

Hyperbaric oxygen exposure 2.4 ATA 90 minutes $2 \times 5$ dayscan not yet used as an alternative therapy to PCOS with insulin resistance. Another study use different pressure and duration is needed.

\section{REFERENCES}

1. Goodarzi MO, Dumesic DA, Chazenbalk G and Azziz R. Polycystic Ovary Syndrome: Etiology, Pathogenesis and Diagnosis. Nature Reviews, Endocrinology. 2011.7. p : 219-231.

2. Strauss III JF, Dunaif A. Molecular mysteries on polycystic ovary syndrome. Mini review. Molecular Endocrinology. 2013;13(6):800-5.

3. Yarali H, Yildiz BO, Demirol A, Zeyneloglu H, Yigit N, Bukulmez O, Koray Z. Co-administration of metformin during $\mathrm{rFSH}$ treatment in patients with clomiphene citrate-resistant polycystic ovarian syndrome: a prospective randomized trial. Human Reproduction. 2002;17(2):289-94.

4. Wilkinson D, Hellbron K, Chapman I. Short report: Patophysiology hyperbaric oxygen therapy improves peripheral insulin sensitivity in humans. Diabetic medicine. 2012:986-9.

5. Al-Waili N, Butler G, Beale J, Abdullah M, Finkelstein M, Merrow $M$, et al. Influences of hyperbaric oxygen on blood pressure, heart rate, and blood glucose levels in patients with diabetes mellitus and hypertension. Archives of medical research. 2006;37:991-7.

6. Harnanik T. Efek oksigenasi hiperbarik terhadap peningkatan aktivitas antioksidan pada penderita Diabetes Mellitus tipe 2. Program Pascasarjana Universitas Airlangga. 2008.

7. Huang S, Czech M. The GLUT4 glucose transporter. Cell Metabolism. 2007:247-52.

8. Thom SR. Oxidative stress is fundamental to hyperbaric oxygen therapy. J Appl Physiol. 2009; 106:988-95.

9. Leney SE and Tavare JM. The molecular basis of insulin-stimulated glucose upatake: signalling, trafficking and potential drug targets. Journal of endocrinology. 2009:1-18.

10. Lira VA, Soltow QA, Long JH, Betters JL, Sellman JE and Criswell DS. Nitric oxyde increases GLUT4 expression and regulates AMPK signalling in skeletal muscle. Am J Physiol Endocrinol Metab. 2007;293:1062-7.

11. Fritz MA and Speroff L. Chronic Anovulation and the Polycystic Ovary Syndrome. In Cinical Gynecologic Endocrinology and Infertility. 8th Eds. Philadelphia: Lippincott Williams \& Wilkin:2011. p. 495-532.

12. Novak M, Madej J and Dziegeil P. Intensity of Cox 2 expression in cell of soft tissue fibrosarcomas in dog as related to grade of tumor malignation. Bull Vet inst Pulawy. 2007;51: 275-9. 
13. Najah, Al-Mousawi, Al-Terahi AM, Mohammad BI and Hassan ES. Effect of sodium valproate on selected reproductive hormone, lipid profiles, and ovarian histology in female rats. Medical Journal of Basrah University. 2008:57-64.

14. Ciaraldi T, El-Roeiy A, Madar Z, Reichart D, Olefsky J, Yen S. Cellular mechanisms of insulin resistance in polycystic ovarian syndrome. Journal of Clinical Endocrinology and Metabolism. 1992; 75(2):577-83.

15. Dunaif A, Xia J, Book C, Schenker E, Tang Z. Excessive insulin receptor serine phosphorylation in cultured fibroblasts and in skeletal muscle. J Clin Invest. 1995;96:801-10.

16. Salehi RV, Alvera and Poretsky. Pathogenesis of polycystic ovary syndrome. J Metab. 2004:358-76.

17. Santoso B. Mekanisme penebalan dinding folikel pada sindroma ovarium polikistik. Program Pascasarjana Universitas Airlangga Surabaya. 2009.

18. Muttaqin DA. Pengaruh Lama Paparan Androgen Terhadap Indeks Resistensi Insulin dan Kadar Asam Lemak Bebas Pada Serum Tikus Model Sindroma Ovarium Polikistik (Penelitian Eksperimental dengan Rattus novergicus sebagai hewan coba). Surabaya: FK UNAIR. 2009.

19. Beloosesky R, Gold R, Almog B, Sasson R, Dantes A, Land-Bracha A. Induction of polycystic ovary by testosterone in immature female rats: modulation of apoptosis and attenuation of glucose/ insulin ratio. International Journal of Molecular Medicine. 2004;14:207-15.

20. Hirshman M, Goodyear L, Wardzala L, Horton ED, Horton ES. Identification of an intracellular pool of glucose transportes from basal and insulinstimulated rat skeletal muscle. The Journal of Biological Chemistry. 1990;285(2):987-91.

21. Kahn B, Rosen A, Bak J, Andersen P, Damsbo P, Lund S, et al. Expression of GLUT1 and GLUT4 glucose transportes in skeletal muscle of human with insulin-dependent Diabetes Mellitus : regulatory effects of metabolic factors. Journal of Clinical Endocrinology and Metabolism. 1992;74 (5):1101-9.

22. Gaster M, Staehr P, Beck-Nielsen H, Schroder HD and Handberg AA. GLUT4 is reduced in slow muscle fibers of type 2 diabetic patients. Diabetes. 2001:1324-9.
23. Rosenbaum D, Haber R, Dunaif A. Insulin resistance in polycystic ovary syndrome: decreased expression of GLUT4 glucose transporters in adipocytes. American Physiological Society. 1993:197-202.

24. Roden M, Price T, Perseghin G, Petersen K, Rothman D, Cline G. Mechanism of free fatty acidinduced insulin resistance in humans. J Clin Invest. 1996;97(12):2859-65.

25. Hayes GR, Lockwood DH. Role of insulin receptor phosphorylation in the insulinomimetic effects of hydrogen peroxide. Proc Natl Acad Sci. 1987;84:8115-9.

26. Pessler D, Rudich A, Bashan N. Oxidative stress impairs nuclear protein binding to the insulin responsive element in the GLUT4 promoter. Diabetologia. 2001;44:2156-64.

27. Yasuda $\mathrm{K}$, Adachi $\mathrm{T}, \mathrm{Gu} \mathrm{N}$, Matsumoto $\mathrm{A}$, Matsunaga T, Tsujimoto G, Tsuda K, Ishihara A. Effects of hyperbaric exposure with high oxygen concentration on glucose and insulin levels and skeletal muscle fiber properties in diabetic rats. Muscle Nerve. 2007;35:337-43.

28. Houstis N, Rosen E, Lander E. Reactive oxygen species have a causal role in multiple forms of insulin resistance. Nature. 2006;440:944-7.

29. Barbieri E, Sestili P. Reactive oxygen species in skeletal muscle signaling. Journal of Signal Transduction. 2012.

30. Gill A and Bell C. Hyperbaric oxygen : its uses, mechanisms of action, and outcomes. QJ Med. 2004;97:385-95.

31. Wijayanto I. Pengaruh HBO pada diabetes mellitus melalui pengukuran HbAlc. Laporan Penelitian Program Pascasarjana Universitas Airlangga. 2000.

32. Rusdiana D. Efek oksigen hiperbarik terhadap peningkatan ekspresi Akt pada Rattus novergicus dengan diabetes mellitus. Surabaya: Laporan Penelitian Universitas Airlangga. 2014.

33. McGee E, Hsueh A. Initial and cyclic recruitment of ovarian follicles. Endocrine Reviews. 2000;21 (2):200-14.

34. Atis A, Aydin Y, Cifti F, Sakiz D, Arslan A, Toklu A. Hyperbaric oxygen increases atresia in normal \& steroid induced PCO rat ovaries. Reproductive Biology and Endocrinology. 2012;10(11). 